\section{ECONOMICS}

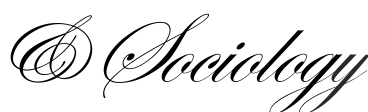

\title{
THE EFFECT OF TWIN SHOCK ON FISCAL SUSTAINABILITY IN INDONESIA
}

\author{
Insukindro, \\ Universitas Gadjah Mada, \\ Yogyakarta, Indonesia, \\ and Bank Indonesia Institute, \\ Jakarta, Indonesia, \\ E-mails:insukindro@ugm.ac.id \\ andinsukindro@gmail.com
}

Received: November, 2017 1st Revision: December, 2017 Accepted: January, 2018

DOI: $10.14254 / 2071-$ 789X.2018/11-1/5

JEL Classification: E62, H63

\begin{abstract}
This paper analyzes the behaviour of fiscal sustainability in Indonesia by using stationarity and cointegration tests and analyzing fiscal reaction function in Indonesia during the period of 2001-2016. It employed economic fluctuations and unanticipated exchange rates to observe the effect of twin shock on fiscal reaction function. In addition, it applied VECM (Vector Error Correction Model) to cover and estimate the behaviour of fiscal reaction function in Indonesia. The VECM is a restricted VAR specified for use with cointegrated series and has nice interpretation with short- and long-run relationships.

Based on the stationarity test, cointegration and fiscal reaction function, the results indicate that there is the fiscal sustainability of the variables used, namely the foreign debt and the public sector primary deficit in the short and long term. The study indicates that the primary deficit is a key determinant of the external debt. These findings also reveal that the efforts of fiscal authorities to optimize the domestic financing sources should be supported because they can reduce the external debt and maintain the fiscal sustainability. In addition, in the long term, economic fluctuations and foreign exchange rate fluctuations have a positive effect on the external debt in Indonesia.
\end{abstract}

Keywords: Fiscal sustainability, primary deficit, fiscal reaction function, economic and exchange rate fluctuations.

\section{Introduction}

The financial crises of 1997/1998 and 2007/2008 have given important lessons for many countries about the emergence of crises which have never existed in the history of developing countries. Other lessons learned are the effects of the crises on public finances and reciprocal relation between financial system and financial health of the government (Bario et al., 2016). The crises also teach people about the role of fiscal policy (such as fiscal stimulus) and external influences on internal and external balances of a country. Neaime and Gaysset (2017) observed the interrelationship of the increase in government budget deficit and the current account balance with the increase in government debt (domestic and external), exchange rate volatility, high inflation and interest rate, declining foreign exchange reserves, declining credit rating, and flow of foreign investment funds. In such relation, fiscal and external sustainability is inevitable. In general, economic sustainability relates to a management system of economic resources that allows current generations to utilize them, but 
at the same time should guarantee that relevant sources can also be utilized by future generations.

Like other developing countries, Indonesia also has experienced similar to the phenomena studied by Naime and Gaysset (2017), especially the relation between the increase in government budget deficit and several macroeconomic variables after the crises of $1997 / 1998$ and 2007/2008.

Figure 1 shows that the realization of Indonesia's State Budget deficit in 2001-2016 tends to increase especially in 2009-2014 although the ratio of the state budget deficit to GDP (Gross Domestic Product) tends to decrease. This indicates that the increase in the state budget deficit is also accompanied by a relatively higher increase in GDP. In Figure 2, it can be seen that the primary deficit (PD) is always higher than the government budget deficit (DEF). The PD value per GDP decreases, but the DEF value per GDP increases and this shows the increasing role of tax in government revenue.

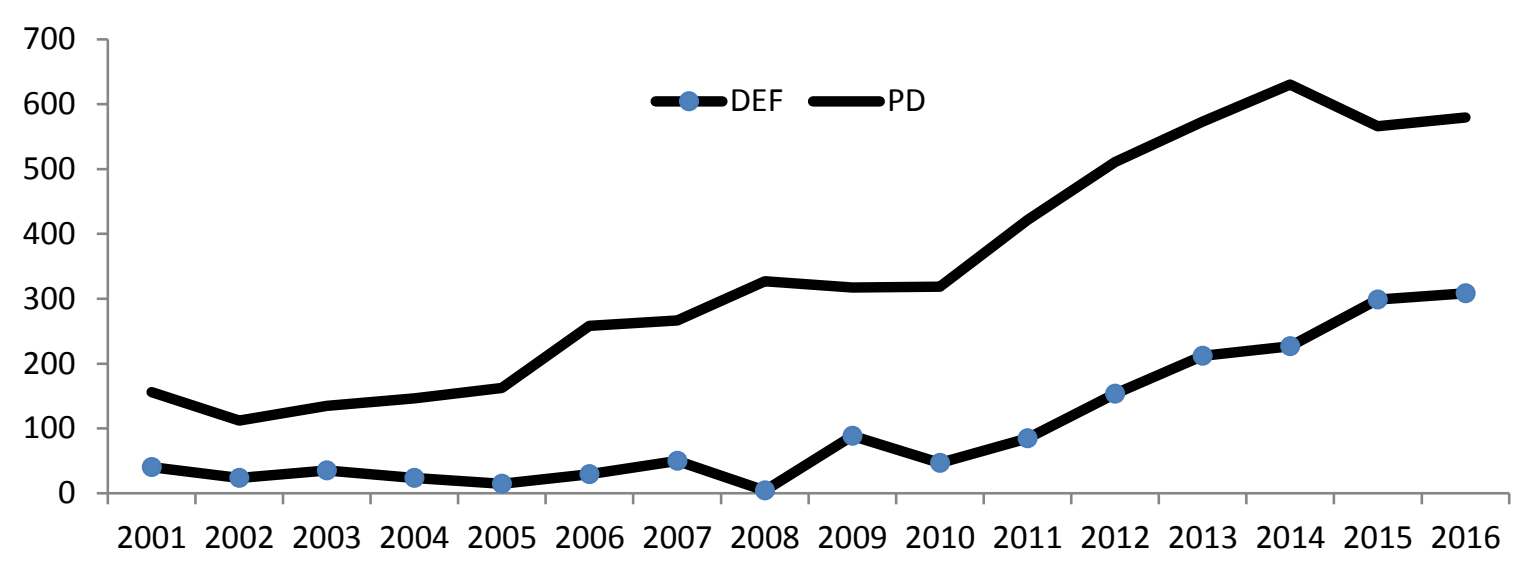

Description: $\mathrm{DEF}=$ State expenditure - State revenue and grants; $\mathrm{PD}=$ State expenditure - Tax revenue, and State expenditure $=$ Central government expenditure + Transfer to regions

Figure 1. Realization of Indonesia's Primary Deficit: 2001-2016 (Trillion Rupiah)

Source: Ministry of Finance (2017).

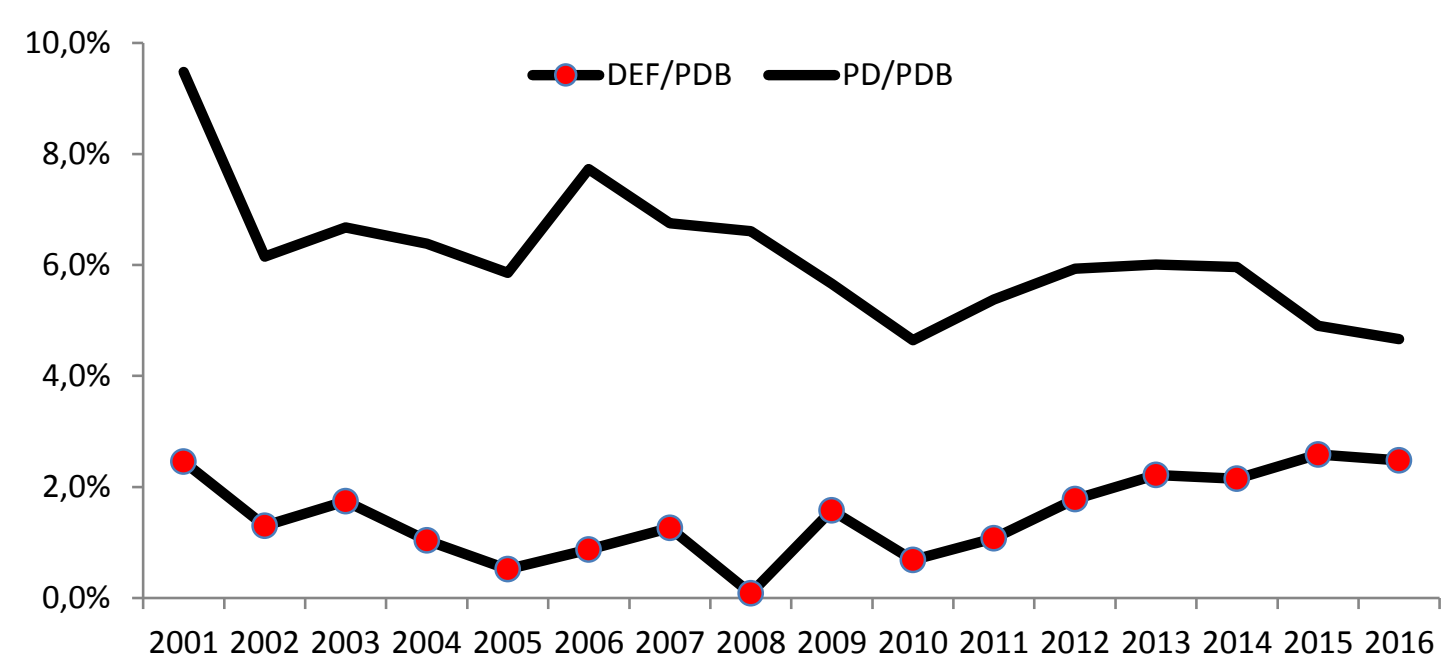

Figure 2. Realization of PD/GDP and DEF/GDP in 2001-2016 Source: Ministry of Finance (2017).

This paper attempts to analyzes the fiscal sustainability by utilizing stationarity and cointegration tests, and estimating fiscal reaction function in Indonesia during the period of 
2001-2016. This study will also estimate the effects of twin shocks (economic and exchange rates fluctuations) on the fiscal sustainability.

\section{Literature review}

The study of fiscal sustainability has been widely conducted in developed and developing countries (for surveys, see for example: Polito and Wickens, 2005; Erhart and Llora, 2007; Adam et al., 2010; Curtasu, 2011; Camarero et al., 2013, Asiama et al., 2014; Neaime, 2015; Neaime and Gaysset, 2017). Polito and Wickens (2005) applied an index of sustainability of the current fiscal stance derived using the intertemporal budget constraint in US, UK, and Germany over 25 years, and revealed that the fiscal stances of all three countries are not sustainable. Ehrhart and LLorca (2007) employed panel cointegration in 20 OECD countries and found that the government spending and revenue are cointegrated. Their findings implied that fiscal policies in these countries are sustainable in the long run. Adam et al. (2010) studied in some Asian countries during the period of 1990-2008 and revealed that the Asian countries concern more on anti-crisis rather than fiscal sustainability in that period. Curtasu (2011) studied in European countries for the period of 1970-2012 and concluded that it is important to understand that assessing the public debt sustainability is a quite difficult process and no simple rule to make an exact conclusion. Camarero (2013) studied in 17 OECD countries for the period of 1990-2008 and found the weakness of fiscal sustainability. Asiama et al. (2014) studied in Ghana during the period of 2004-2013 and revealed that the government's fiscal behavior is line with the intertemporal budget constraint, the fiscal adjustment is very low, and there is evidence of the fiscal pressure during the election cycles. Neaime (2015) studied in France, Germany, Greece, Ireland, Italy, Portugal and Spain over the period of 1977-2013 and found that some EU's countries could face a debt and fiscal crisis unless timely fiscal adjustment measures are introduced in the near future. Neaime and Gaysset (2017) studied in a selected MENA countries and revealed that fiscal and exchange policies are sustainable in Tunisia and Maroko but the external debt and exchange rate policies are not sustainable in Egypt and Jordan. In general, their study employed unit root test, cointegration and fiscal reaction function to analyse fiscal sustainability in the countries they observed.

The role of shock variable in the economy has also been the concern of economists, especially the New Neoclassical Synthesis' economists. Their model, for example, discusses the effect of aggregate supply and demand shocks on real interest rates and inflation (Hubbard et al., 2014, Ch. 11). Furthermore, this study will also estimate the effects of twin shocks (economic and exchange rates fluctuations) on fiscal sustainability, in addition to the aforementioned three approaches mentioned above.

\section{Methodological approach}

\subsection{Definition of fiscal sustainability}

Raymundo (2016) stated that fiscal sustainability relates to a state in which public debt or government debt or fiscal deficits remains within tolerable limits because the government continues with its expenditure programs. The limit of public debt or the tolerable fiscal deficit should allow the government to make regular payments of interest and principal for both domestic and foreign debts, and gradually reduce long-term deficit expenditures and maintain a good credit rating in order to maintain easier access to new loans if necessary.

Adam et al. (2010) argued that fiscal sustainability is related to a status in which government budgets can be financed smoothly without creating or stimulating extraordinary increases in public debt (or money supply) over time. If this status is met, the government 
budget is said to be sustainable, or vice versa. According to them, there are two fiscal sustainability concepts, namely static sustainability that reflects government's ability to finance its budget from period to period, and dynamic sustainability related to the government's ability to pay off its debt/liabilities in the long term. The indicators of fiscal sustainability that are often used include (ratio to GDP): public debt, surplus or primary deficit or primary balance, fiscal surplus, fiscal expenditure, government revenue and debt payment.

\subsection{Model of Fiscal Sustainability}

A theory commonly used to examine fiscal sustainability is intertemporal government budget constraint (for reference, see for example: Polito and Wickens, 2005; Bohn, 2007; Hubbard et al., 2014: Ch.15; Asiama et al., 2014). This study used the intertemporal government budget constraint model as shown in equation (1) below:

$$
G_{t}+T R_{t}+i_{t} B_{t-1}=T_{t}+\Delta B_{t}
$$

The left-hand side of equation (1) is the use of government revenue \{namely: government's expenditure on goods and services (G), transfer payment $(T R)$ and interest payment $(i B)\}$ The right-hand side of equation (1) is the source of government revenue $\{$ namely: tax revenue $(\mathrm{T})$ and new sale of government bonds $(\Delta B)\}$. Furthermore, a primary budget deficit (PD) can be formulated as follows:

$$
G_{t}+T R_{t}-T_{t}+i_{t} B_{t-1}=\Delta B_{t}
$$

The left-hand side of equation (2) is a budget deficit. The primary deficit can also be written as:

$$
P D_{t}=G_{t}+T R_{t}-T_{t}
$$

The substitution of equation (3) into equation (2) will obtain:

$$
\begin{aligned}
& G_{t}+i_{t} B_{t-1}=\Delta B_{t} \\
& P D_{t}+\left(1+i_{t}\right) B_{t-1}=B_{t}
\end{aligned}
$$

\subsection{Empirical Model of Fiscal Sustainability and Methodology}

This study will examine fiscal sustainability as reflected in the long-term relationship between primary deficit and (domestic and external) public debt. Accordingly, there are 3 steps to be taken.

\section{1). Unit roots test and cointegration}

The first step is taken to find out whether the variables used in this study (PD and B) are stationary $\{\mathrm{I}(0)\}$ or not stationary $\{\mathrm{I}(1)\}$. If the variables are $\mathrm{I}(1)$, it indicates that sufficient condition for fiscal sustainability is fulfilled, but a necessary condition is not yet fulfilled and, therefore, it requires cointegration approach in the second step (Bohn, 2007; Muzenda, 2014; Krajewski et al., 2016).

$$
P D_{t}=\alpha_{0}+\alpha_{l} B_{t}+\eta_{1 t}
$$




$$
B_{t}=b_{0}+b_{1} P D_{t}+\eta_{2 t}
$$

Where PD is the primary deficit and B is the (domestic and external) debt.

2). Fiscal reaction function

The third step to analyze fiscal sustainability is by estimating the fiscal reaction function. This function is a behavioral equation of the fiscal variable being observed with other prevailing macroeconomic, fiscal and economic conditions. If the cointegration test indicates that the observed variables are cointegrated, VECM (Vector error correction model) can be used to find out the fiscal reaction function (Bohn, 2007; Muzenda, 2014). The most advantage of VECM is that it is a restricted VAR (Vector Autoregression) designed for use with cointegrated series and has nice interpretation with short- and long-run relationships (Hunter et al., 2017, p. 50). This study will apply VECM as follows.

$$
\begin{aligned}
& \Delta P D_{t}=\sum_{i} \alpha_{i} L^{i} \Delta B_{t}+\sum_{i} \beta_{i} L^{i-1} \Delta P D_{t^{-}} \gamma_{1} L \eta_{i t}+\varepsilon_{1 t} \\
& \Delta B_{t}=\sum_{i} \delta_{i} L^{i} \Delta P D_{t}+\sum_{i} \theta_{i} L^{i-1} \Delta B_{t}-\gamma_{1} L \eta_{2 t}+\varepsilon_{1 t}
\end{aligned}
$$

Where $\Delta \mathrm{X}_{\mathrm{t}}=(1-\mathrm{L}) \mathrm{X}_{\mathrm{t}}$ and $\mathrm{L}$ is lag operator.

Furthermore, the following model will be used to observe the fiscal reaction function with the shock variable $(\mathrm{S})$.

$$
\Delta Y_{t}=\sum_{i} a_{i} L^{i} \Delta Z_{t}+\sum_{i} b_{i} L^{i-1} \Delta Y_{t}-d_{i} L \eta_{i t}+e_{1} \Delta S_{t}+e_{2} L S_{t}+\varepsilon_{t}
$$

\subsection{Definition of Estimated Empirical Model Variable}

This study uses the following variables. Primary deficit (PD) is central government expenditure $(\mathrm{G})$ plus transfer payment to the region (TR) minus tax (T). Domestic debt (BD) is the value of domestic financing in the realization of State Budget, while external debt (BF) is the withdrawal of gross external loans in the realized state budget. In the estimated model, twin shock consists of output shock or output gap, SG, and exchange rate shock (SK). The output shock is the difference between actual output and potential output, while the exchange rate shock is the difference between actual exchange rate and its trend. HP filter is used to obtain potential output value and exchange rate trend. The data are quarterly data for the period of 2001-2016.

Table 1. Variable Definitions

\begin{tabular}{lcccc}
\hline \multicolumn{1}{c}{1} & Symbol & Description & Unit & Source \\
\hline Nominal GDP & 2 & 3 & 4 & 5 \\
\hline Real GDP & $P D B$ & Current prices & Billion Rp & BPS \\
\hline $\begin{array}{l}\text { Central Government } \\
\text { Expenditure }\end{array}$ & $R P D B$ & $\begin{array}{c}\text { GDPconstant prices } \\
2010=100\end{array}$ & Billion Rp & BPS \\
\hline Tax Revenue & $G$ & & Billion Rp & $\begin{array}{c}\text { Ministry of } \\
\text { Finance (MoF) }\end{array}$ \\
\hline $\begin{array}{l}\text { Transfer to Regions and } \\
\text { Village Funds }\end{array}$ & $T R$ & & Billion Rp & MoF \\
\hline
\end{tabular}




\begin{tabular}{|c|c|c|c|c|}
\hline 1 & 2 & 3 & 4 & 5 \\
\hline Primary Deficit & $P D$ & $P D=G+T R-T$ & Billion Rp & \\
\hline Domestic debt & $B D$ & Domestic financing & Billion Rp & $\mathrm{MoF}$ \\
\hline External debt & $B F$ & $\begin{array}{l}\text { Withdrawal of gross } \\
\text { external loans }\end{array}$ & Billion Rp & $\mathrm{MoF}$ \\
\hline Potential GDP & $R P D B^{*}$ & $\begin{array}{c}\text { Obtained by using HP } \\
\text { Filter }\end{array}$ & Billion Rp & \\
\hline Output gap & $S G$ & $S G=R P D B-R P D B^{*}$ & Billion $\mathrm{Rp}$ & \\
\hline Exchange rate & $K$ & $\mathrm{Rp} / \mathrm{USD}$ & Rp/USD & $\begin{array}{l}\text { Bank of } \\
\text { Indonesia }\end{array}$ \\
\hline $\begin{array}{l}\text { Value of exchange rate } \\
\text { trend }\end{array}$ & $K^{*}$ & $\begin{array}{c}\text { Obtained by using HP } \\
\text { Filter }\end{array}$ & Rp/USD & \\
\hline Exchange rate shock & $S K$ & $S K=K-K^{*}$ & $\mathrm{Rp}$ & \\
\hline
\end{tabular}

As previously discussed, several procedures are carried out to estimate the empirical model. First, the stationarity tests of the variables used in the study employ Dickey-Fuller (DF), Augmented Dickey-Fuller (ADF) and Kwiatkowski-Phillips-Schmidt-Shin (KPSS) tests. Through the three tests, it can be seen whether the observed variable integrates zero or I (0) or integrates one or I(1). If all variables are I(1), the next step is to observe the long-term relationship or sustainability between variables by using Johansen's cointegration test. Using the method of trace statistic and maximum eigenvalue of Johansen's cointegration test can detect the existence of cointegration between variables.

Furthermore, if the cointegration between variables is found, the Vector Error Correction Model (VECM) of fiscal reaction function could be estimated to detect short-term relationships between variables. The fiscal reaction function would be chosen based on the estimation results of equations (6.a and 6.c) above. After the best error correction model, i.e. the estimation model that meet the ECM criterion, is chosen, the next step is to estimate the best VECM equation by including the twin shock variable as formulated in equation (7). In this study, there are two shocks, namely output gap or SG and foreign exchange rate shock or SK. Therefore, the fiscal reaction function to be estimated is the modification of equation (7) as shown below ${ }^{1}$.

$$
\Delta Y_{t}=\sum_{i} a_{i} L^{i} \Delta Z_{t}+\sum_{i} b_{i} L^{i-1} \Delta Y_{t}-d_{i} L \eta_{i t}+e_{1} \Delta S G_{t}+e_{2} L S G_{t}+e_{3} \Delta S K_{t}+e_{4} L S K_{t}+\varepsilon_{t}
$$

The hypothesis testings are as follows:

Table 2. Hipothesis testing for equation (8)

\begin{tabular}{llll}
\hline Ho: $\mathrm{e}_{1}=0$ & Ho: $\mathrm{e}_{2}=0$ & Ho: $\mathrm{e}_{3}=0$ & Ho: $\mathrm{e}_{4}=0$ \\
\hline Ha: $\mathrm{e}_{1} \neq 0$ & Ha: $\mathrm{e}_{2} \neq 0$ & Ha: $\mathrm{e}_{3} \neq 0$ & Ha: $\mathrm{e}_{4} \neq 0$ \\
\hline
\end{tabular}

If only e 1 and $\mathrm{e} 3$ are different from zero and statistically significant, it means that twin shock occurred only in the short term. However, if only e2 and e4 are different from zero and statistically significant, it means twin shocks are continuously for the long term.

\footnotetext{
${ }^{1}$ By using a single period quadratic cost function, Insukindro (1990, pp. 100-107, and 1998) could derive buffer stock model of money demand with unanticipated reserve money or ECM (Error Correction Model) with shock variable as follows: $\Delta \mathrm{md}_{\mathrm{t}}=\alpha_{1} \Delta \mathrm{y}_{\mathrm{t}}+\alpha_{2} \Delta \mathrm{r}_{\mathrm{t}}-\beta \varepsilon_{\mathrm{t}-1}+\gamma_{1} \Delta \mathrm{S}_{\mathrm{t}}+\gamma_{2} \mathrm{~S}_{\mathrm{t}-1}$, where $\Delta \mathrm{x}_{\mathrm{t}}=\mathrm{x}_{\mathrm{t}}-\mathrm{x}_{\mathrm{t}-1,}$, md is the real money demand, $\mathrm{y}$ is the real income, $\mathrm{r}$ is the interest rate, $\varepsilon$ is the residual of related cointegration regression and $\mathrm{S}$ is the shock variable (namely the unticipated reserve money).
} 


\section{Estimation Results and Discussion}

\subsection{Stationarity Test}

Table 3 shows the stationarity test results of the variables in this study using the Dickey-Fuller (DF), Augmented Dickey-Fuller (ADF), and Kwiatkowski-Phillips-SchmidtShin (KPSS) tests. The test results using DF and ADF show that the observed variables are not stationary or I(1), while the KPSS test reveals that only BD is not stationary. Furthermore, the stationarity tests for all variables in the first different form indicate that all observed variables are stationary. Therefore, it can be said the hypothesis that these variables are I(1) could not be rejected.

Table 3. Stationarity Test

\begin{tabular}{cccc}
\hline & DF test & ADFtest & KPSS \\
\hline$P D_{t}$ & -0.527 & -3.339 & 0.119 \\
\hline$B D_{t}$ & -0.803 & -2.985 & $0.500^{* *}$ \\
\hline$B F_{t}$ & -0.701 & -1.868 & 0.133 \\
\hline$\Delta P D_{t}$ & $-9.321^{* *}$ & $-9.239^{* *}$ & 0.088 \\
\hline$\Delta B D_{t}$ & $-9.525^{* *}$ & $-9.376^{* *}$ & 0.143 \\
\hline$\Delta B F_{t}$ & $-3.068^{*}$ & -3.106 & 0.087
\end{tabular}

* (**) indicates the rejection of the null hypothesis at $5 \%(1 \%)$ of significance level.

\subsection{Cointegration test}

After the stationarity tests are conducted stating that all variables are I(1), the next step is to perform a cointegration test by modifying equations (5a) and (5b) and substituting $\mathrm{B}$ with the domestic debt (BD) and external debt (BF), so that there are three variables, namely $\mathrm{PD}, \mathrm{BD}$ and BF. Accordingly, a cointegration test using Johansen's method is applied. The estimation results are shown in Table 4.

Table 4. Cointegration Test of Johansen-Lag Interval 1 to 2

\begin{tabular}{lccc}
\hline $\mathrm{H}_{0}$ & $\mathrm{r}=0$ & $\mathrm{r} \leq 1$ & $\mathrm{r} \leq 2$ \\
$\mathrm{H}_{\mathrm{a}}$ & $\mathrm{r}=1$ & $\mathrm{r}=2$ & $\mathrm{r}=3$ \\
\hline Eigen Value & 0.717833 & 0.099887 & 0.068027 \\
Trace Statistic & $87.89756^{* *}$ & 10.71683 & $10.71683^{*}$ \\
Maximum Eigen Statistic & $77.18073^{* *}$ & 6.419318 & $4.297511^{*}$ \\
\hline Critical value (5\%) Trace statistic & 29.79707 & 15.49471 & 3.841466 \\
Critical value (5\%) Max- Eigen stat. & 21.13162 & 14.26460 & 3.841466 \\
\hline$*(* *)$ indicates the rejection of the null hypothesis at 5\% (1\%) of significance level. \\
Trace test and Max-eigen value test indicate 1 cointegrating eqn at the 0.05 level \\
\hline
\end{tabular}

Table 4 reports the possibility of three long-term relationships or cointegration. However, based on the trace statistic value and eigen value, it can be concluded that there is one cointegration. Therefore, the existence of fiscal sustainability in Indonesia could not be rejected. Furthermore, an estimation using VECM finds out the appropriate short-term and long-term relationship between the three variables. 


\subsection{Fiscal Reaction Function: VECM Approach and Twin Shock}

The fiscal reaction function is estimated by modifying equations (6a) and (6b) by substituting the variable $\mathrm{B}$ with $\mathrm{BD}$ and $\mathrm{BF}$ into both equations. The results of the VECM estimation of the fiscal reaction function are then chosen through the criterion of selecting error correction (ECM) that the coefficient of cointegrating regression residual or CointEq is between 0 and 1 as well as statistically significant, and the best results are shown in the second column of Table 5 .

Table 5. Results of VECM Estimation

\begin{tabular}{|c|c|c|}
\hline \multicolumn{3}{|l|}{ Cointegrating Equation: } \\
\hline & Coint & Coint \\
\hline $\mathrm{BF}(-1)$ & 1.000000 & 1.00000 \\
\hline \multirow{2}{*}{$\mathrm{PD}(-1)$} & $0.206879 * * *$ & $0.23488 * * *$ \\
\hline & {$[7.72040]$} & {$[5.53566]$} \\
\hline \multirow[t]{2}{*}{$\mathrm{BD}(-1)$} & $-0.46250 * * *$ & $-0.51340^{* * *}$ \\
\hline & {$[-10.7445]$} & {$[-7.57265]$} \\
\hline \multirow[t]{2}{*}{$\mathrm{C}$} & $-11834.96000^{* * * *}$ & $-12634.40000^{* * *}$ \\
\hline & {$[-8.39063]$} & {$[-6.16807]$} \\
\hline \multicolumn{3}{|l|}{ Error Correction: } \\
\hline & $\mathrm{D}(\mathrm{BF})$ & $\mathrm{D}(\mathrm{BF})$ \\
\hline \multirow[t]{2}{*}{ CointEq } & $-0.802393 * * *$ & $-0.25011 *$ \\
\hline & {$[-5.34102]$} & {$[-1.68194]$} \\
\hline \multirow[t]{2}{*}{$\mathrm{D}(\mathrm{BF}(-1))$} & $-0.350289 * *$ & $-0.77237 * * *$ \\
\hline & {$[-1.96033]$} & {$[-4.80011]$} \\
\hline \multirow[t]{2}{*}{$\mathrm{D}(\mathrm{BF}(-2))$} & -0.145614 & $-0.31904 * *$ \\
\hline & {$[-1.05434]$} & {$[-2.44673]$} \\
\hline \multirow[t]{2}{*}{$\mathrm{D}(\mathrm{PD}(-1))$} & $0.180331 * * *$ & $0.084972 * * *$ \\
\hline & [ 6.89976] & {$[2.79475]$} \\
\hline \multirow[t]{2}{*}{$\mathrm{D}(\mathrm{PD}(-2))$} & $0.130278 * * *$ & $0.078746 * * *$ \\
\hline & [ 6.68147] & [3.45208] \\
\hline \multirow[t]{2}{*}{$\mathrm{D}(\mathrm{BD}(-1))$} & $-0.404515 * * *$ & $-0.17374 * * *$ \\
\hline & [-7.36207] & {$[-2.68226]$} \\
\hline \multirow[t]{2}{*}{$\mathrm{D}(\mathrm{BD}(-2))$} & $-0.282988 * * *$ & $-0.16203 * * *$ \\
\hline & {$[-6.97405]$} & {$[-3.97943]$} \\
\hline \multirow[t]{2}{*}{$\mathrm{D}(\mathrm{SK})$} & & -0.80621 \\
\hline & & {$[-0.42454]$} \\
\hline \multirow[t]{2}{*}{ SK(-1) } & & $4.085785^{* * * *}$ \\
\hline & & [2.73362] \\
\hline \multirow[t]{2}{*}{$\mathrm{D}(\mathrm{SG})$} & & -0.02757 \\
\hline & & {$[-0.36462]$} \\
\hline \multirow[t]{2}{*}{ SG(-1) } & & $0.260349 * *$ \\
\hline & & {$[2.59048]$} \\
\hline Adj. R-squared & 0.773287 & 0.856146 \\
\hline Sum sq. resids & $4.37 \mathrm{E}+09$ & $2.57 \mathrm{E}+09$ \\
\hline S.E. equation & 8996.352 & 7166.187 \\
\hline F-statistic & 35.10853 & 36.70907 \\
\hline ADF stat for residual & $-6.717211 * * *$ & $-5.99808^{* * * *}$ \\
\hline
\end{tabular}


The second column of Table 5 shows that the CointEq coefficient for the BF variable is negative, between 0 and 1 and statistically significant (regression coefficient $=0.80239$ and its t-statistic $=-5.3410$ ). In addition, the stationarity test of the residual equations using ADF test (statistic value of $\mathrm{ADF}=-6.7172$ ) reveals that the related residual is stationary or I (0). In other words, the latter result indicates the absence of heteroscedasticity and serial correlation.

In the short term, the primary deficit (PD) has a positive and statistically significant effect on the gross external debt (BF), while the domestic debt has a negative and statistically significant effect on the gross external debt. Similarly, based on cointegration regression, the results also reveal that $\mathrm{PD}$ variable has a positive effect on $\mathrm{BF}$, while $\mathrm{BD}$ variable has a negative effect. In other words, if the primary deficit increases, it will stimulate an increase in the external financing source or external debt and increased the domestic financing sources will reduce the external debt in order to maintain fiscal sustainability in Indonesia.

The next step is to estimate the effect of twin shock on external debt based on the best ECM results (equation 7) as explained above. Accordingly, the equation (8) is estimated as an extension of the best estimation result. The estimation results are reported in the third column of Table 5 and show that the CointEq coefficient for the BF variable is negative, between 0 and 1 as well as statistically significant (the regression coefficient $=-0.2501$ and its $\mathrm{t}$ statistic $=-1.6819)$. In addition, the stationarity test of the residual equation using ADF test (statistic value of $\mathrm{ADF}=-5.9980$ ) shows that the related residual is stationary or I (0).

The effect of twin shock can be seen on the coefficients of $\Delta \mathrm{SG}_{\mathrm{t}}$ and $\mathrm{SG}_{\mathrm{t}-1}$ for the output gap, and the coefficients of $\Delta \mathrm{SK}_{\mathrm{t}}$ and $\mathrm{SK}_{\mathrm{t}-1}$.for the unanticipated change of exchange rate The results of the study show that the t-statistic values of coefficients of $\Delta \mathrm{SG}_{\mathrm{t}}$ and $\Delta \mathrm{SK}_{\mathrm{t}}$ are statistically insignificant (-0.36462 and -0.42454 , respectively), meaning there is no effect of both shocks in short term. On the other hand, the t-statistic values of the coefficients of $\mathrm{SG}_{\mathrm{t}-1}$ and $\mathrm{SK}_{\mathrm{t}-1}$ are positive and statistically significant (2.5905 and 2.7336 respectively). These results indicate that the twin shock will have an effect on the external debt in the long term. Therefore, an unanticipated increase in output and exchange rates will increase the external debt. The positive impact of output shock reveals that if an increase in economic activity requiring a large fiscal stimulus will also increase the need for the external debt. Rupiah depreciation or USD appreciation, for example, may increase the value of the external debt.

\section{Conclusion}

Based on the stasionarity and cointegration tests as well as the fiscal reaction function, the results of the study reveal the existence of fiscal sustainability and the positive effect of related twin shock on the behaviour of fiscal sustainability in Indonesia.

This study finds that the primary deficit positively affects the public sector external debt in short and long term. The findings also indicate that the efforts of fiscal authorities to control primary deficit and optimize of domestic financing sources need to be continued to maintain fiscal sustainability in Indonesia.

The twin shock variables indicate that economic fluctuations and exchange rates shock in the long-term have a positive effect on the fiscal reaction function. The estimation model using twin shock variables are also able to more profoundly explain the fiscal sustainability model than that without the twin shock variables. These findings suggest that in the long term the external shock (exchange rate fluctuations) and internal shock (economic fluctuations) determine the behaviour of fiscal authorities in maintaining fiscal sustainability in Indonesia. 


\section{Acknowledgement}

The author takes this opportunity to the Faculty of Economics and Business, Universitas Gadjah Mada, Yogyakarta, Indonesia for financial support to carry out this research.

\section{References}

Adam, C., Ferrarini, B. and Park, D. (2010). Fiscal Sustainability in Developing Asia. ADB Economics Working Paper Series, 205, June.

Asiama, J., Akosah, N. and Owusu-Afriyie, E. (2014). An Assessment of Fiscal Sustainability in Ghana. Bank of Ghana Working Paper, WP/BOG/2014/09.

Bario, C., Lombardi, M. and Zampolli, F. (2016). Fiscal Sustainability and the Financial Cycle. BIS Working Paper, No. 552.

Bohn, H. (2007). Are Stationarity and Cointegration Restrictions Really Necessary for the Intertemporal Budget Constraint. Journal of Monetary Economics, 54, 1837-1847. DOI:10.1016/j.jmoneco.2006.12.012.

Camarero, M., Carrion-i-Silvestre, J. L. and Tamarit, C. (2013). The Relationship between Debt level and Fiscal Sustainability in OECD. RIAE Working Paper, 2013/15.

Curtasu, A. R. (2011). How to Assess Public Debt Sustainability: Empirical Evidence for Advanced European Countries. Romanian Journal of Fiscal Policy, 2(2), 20-43.

Ehrhart, C. and Llorca, M. (2007). A Global Perspective of Fiscal Sustainability: Evidence from a Panel of 20 OECD Countries. Paper presented at the $11^{\text {th }}$ International Conference on Macroeconomic Analysis and International Finance in University of Crete, Rethymno, Greece, May 24-26.

Hubbard, R. G., O'Brien, A. P and M. Rafferty, M. (2014). Macroeconomics. Harlow, Essex: Pearson Education, Inc.

Hunter, J., Burke, S. P. and Canepa, A. (2017). Multivariate Modelling of Non-Stasionary Economic Time Series. Palgrave Texts in Econometrics.

Insukindro (1990). The Short- and Long-Term Determinants of Money and Bank Credit Markets in Indonesia. Ph.D Thesis, University of Essex, UK, Unpublished.

Insukindro (1998). Pendekatan Stok Penyangga Permintaan Uang: Tinjauan Teoritik dan Sebuah Studi Empirik di Indonesia (Buffer Stock Approach to Money Demand: Theoretical Review and an Empirical Study in Indonesia). Economics and Finance in Indonesia, XLVI(4), 451-471.

Krajewski, P., Mackiewicz, M. and Szymanska, A. (2016). Fiscal Sustainability in Central and Eastern European Countries - A Post-Crisis Assessment. Prague Economic Papers, 25(02), 175-188. DOI:10.18267/j.pep.553.

Ministry of Finance (2017), Realisasi Triwulanan APBN (Quaterly Realization of Indonesian Government's Budget) 2000-2016.

Muzenda, A. (2014). An Empirical Assessment of Fiscal Sustainability in South Africa. Journal of Economics and Sustainable Development, 5(23), 1-6.

Neaime, S. (2015). Sustainability of Budget Deficits and Public Debt in Selected European Union Countries. Journal of Economic Asymmerics, 12, 1-21. DOI: 10.1016/j.jeca.2014.10.002.

Neaime, S. and Gaysset, I. (2017). Sustainability of Macroeconomic Policies in Selected Mena Countries: Post Financial and Debt Crises. Research in International Business and Finance, 40, 129-140. DOI: 10.1016/j.ribaf.2017.01.001.

Polito, V. and Wickens, M. (2005). Measuring Fiscal Sustainability. Centre for Dynamic Macroeconomic Analysis Conference (CDMC), 05/03, June.

Raymundo, R. B. (2016). Fiscal Sustainability and Sovereignty Issues under an Asean Economic Union. Paper presented at the DSLU Research Congress, De La Salle University, Manila, Philippines, March 7-9. 